\title{
Differentiation of Micrococcus luteus and Micrococcus varians on the Basis of Catalase Isoenzymes
}

\author{
By R. H. FOX \\ Department of Biology, The American University, Washington, D.C. 20016, U.S.A
}

(Received 3 June 1975; revised 4 November 1975)

\begin{abstract}
SUMMARY
Crude extracts prepared from four Micrococcus varians strains, II $M$. luteus strains and four laboratory isolates subsequently classified with $M$. luteus were assayed for catalase activity following electrophoresis on polyacrylamide gels. The enzyme patterns produced from the $M$. varians strains exhibited three catalase isoenzymes which were distinguished into two types of patterns depending upon the location of the major band. The extracts from all the $M$. luteus strains produced the same pattern, composed of two catalase isoenzymes of similar electrophoretic mobility. For both species the isoenzyme patterns agreed with the differentiation based on biochemical properties. The catalase activity staining method was shown to be a restricted yet reliable assay in the intrageneric but not intraspecies differentiation of yellow-pigmented micrococci.
\end{abstract}

\section{INTRODUCTION}

Currently, the aerobic Gram-positive yellow micrococci are divided into two species in the genus Micrococcus (Baird-Parker, 1974). Most of the strains now distributed between these species were previously designated as distinct Micrococcus spp., whereas others were classified as species of the genera Sarcina and Staphylococcus. The species differentiation of these strains is based on the guanine plus cytosine (GC) content in DNA (Boháček, Kocur \& Martinec, 1967, 1970; Kocur, Bergan \& Mortensen, 1971; Rosypal, Rosypalová \& Hořješ, I966; Rosypalová, Boháček \& Rosypal, I966; Venner, 1967) and on their action on glucose and nitrate. Micrococcus luteus (Kocur, Páčová \& Martinec, 1972) has a GC content in DNA of 70.7 to $75.5 \%$, is asaccharolytic and does not reduce nitrates. Micrococcus varians (Kocur \& Martinec, I972) has a GC content in DNA of 66 to $72 \%$, produces acid from glucose, and generally reduces nitrates. Catalase is produced by all strains of both species.

Fox (1975) reported additional evidence supporting the concept of a close phenetic relatedness between $M$. luteus and $M$. varians, based on common intrageneric protein electrophoretic patterns which did not differentiate between representative strains of these species. Therefore, it was of interest to determine whether catalase (hydrogen peroxide oxidoreductase, EC. I.II.I.6), universally produced by these bacteria, would display differential inter- and/or intraspecific isoenzyme patterns on polyacrylamide gels. This paper describes the catalase activity patterns obtained from 19 strains of yellow micrococci. 
Table I. Biochemical properties of tested strains

\begin{tabular}{|c|c|c|c|c|c|c|c|c|}
\hline Species & $\begin{array}{l}\text { Designation } \\
\text { on receipt }\end{array}$ & Source $\ddagger$ &  & 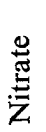 & $\begin{array}{l}\text { 思 } \\
\text { 吾 }\end{array}$ & 声 & 总 & $\frac{\mathscr{J}}{\tilde{J}}$ \\
\hline Micrococcus luteus & M. luteus* & ATCC4698 & - & - & - & - & + & + \\
\hline M. luteus & M. flavus & ATCCIO240 & - & - & + & + & - & + \\
\hline M. luteus & M. flavus $8 \mathrm{I}$ & AUCC & - & - & - & - & - & + \\
\hline M. luteus & M. luteus 1226 & AUCC & - & - & + & + & - & + \\
\hline M. luteus & M. lysodeikticus PII9 & AUCC & - & - & - & - & + & + \\
\hline M. luteus & M. lysodeikticus XL30 & AUCC & - & - & - & - & + & + \\
\hline M. luteus & M. sodonensis & ATCCI I 880 & - & - & - & + & - & + \\
\hline M. luteus & Sarcina flava 22 & AUCC & - & - & - & \pm & + & + \\
\hline M. luteus & S. lutea & ATCC38I & - & - & - & - & + & + \\
\hline M. luteus & S. lutea $\mathrm{SL} 233$ & AUCC & - & - & + & + & + & + \\
\hline M. luteus & S. subflava & ATCC 7468 & - & - & + & + & - & + \\
\hline M. varians & Staph. lactis $\dagger$ & ATCCI5306 & + & + & - & + & - & + \\
\hline M. varians & M. varians & ATCC 399 & + & + & - & + & - & + \\
\hline M. varians & S. aurantiaca & ATCCI46 & + & - & + & + & - & + \\
\hline \multirow[t]{5}{*}{ M. varians } & M. pulcher & ATCCI 5936 & + & + & - & - & - & + \\
\hline & & YPO2 & - & - & - & + & - & + \\
\hline & & YPO7 & - & - & + & + & + & + \\
\hline & & YPIO & - & - & + & + & - & + \\
\hline & & YPI 5 & - & - & + & + & - & + \\
\hline
\end{tabular}

,+ Positive test;,- negative test; \pm , weak positive test.

* Neotype strain, $M$. luteus.

$\dagger$ Neotype strain, $M$. varians.

¥ ATCC, American Type Culture Collection, Rockville, Maryland, U.S.A.; AUCC, Culture Collection, Department of Biology, The American University; YP, strains isolated in this laboratory by R. H. Fox from dust, air and soil.

$\S$ Positive test indicates acid from glucose aerobically and anaerobically.

\section{METHODS}

Bacteria and cultural conditions. The bacteria tested are listed in Table I. Cultures for the preparation of crude cell-free extracts were grown in nutrient broth (Difco), with shaking, at $30{ }^{\circ} \mathrm{C}$ for 20 to $30 \mathrm{~h}$. The four Gram-positive yellow micrococci isolated in this laboratory were purified by standard techniques from nutrient agar plates inoculated with dust, soil and air from various sources.

Biochemical tests. Acid from glucose was tested with I \% (w/v) glucose added aseptically to the Hugh \& Leifson oxidation-fermentation medium (Difco) with and without a mineral oil seal. Nitrate reduction (0.I \% nitrate broth, Difco), starch hydrolysis (I \%, w/v, soluble starch in nutrient agar, Difco), gelatin liquification (nutrient gelatin, Difco) and urease production $(2 \%, \mathrm{v} / \mathrm{v}$, urea added aseptically to urea agar base, Difco) were determined by methods described in the 9 th edition of the Difco Manual. Catalase was detected by emulsifying growth from overnight cultures on nutrient agar on a glass slide in a drop of $3 \%(\mathrm{v} / \mathrm{v}) \mathrm{H}_{2} \mathrm{O}_{2}$ and observing the formation of bubbles.

Preparation of cell-free extracts and electrophoretic procedures. The methods of cell disruption and polymerization of $7 \%$ polyacrylamide gels were described by Fox \& McClain (I974). The separating gels were prepared at least one day before use and stored at $4{ }^{\circ} \mathrm{C}$. Samples of $50 \mu \mathrm{l}$, containing approximately $250 \mu \mathrm{g}$ protein, were applied to the gels. Protein was determined by the method of Lowry et al. (195I) using bovine serum albumin as a standard. 
R. H. FOX

Catalase activity stain on gels. Visualization of catalase on gels following electrophoresis was by the diaminobenzidine-peroxidase method of Gregory \& Fridovich (1974). Control staining assays consisted of duplicate gels of each sample, one of which was pre-soaked in the mixture from which the peroxidase reagent was eliminated, followed by soaking the gels in the $\mathrm{H}_{2} \mathrm{O}_{2}$ substrate solution; only peroxidase active bands develop on gels in this assay.

\section{RESULTS AND DISCUSSION}

Results of the biochemical tests demonstrated that the $M$. luteus and $M$. varians strains could be distinguished by their actions on glucose and nitrate reduction (Table I). The reactions of the four isolates indicated that they belonged to the species $M$. luteus (Kocur \& Martinec, 1972). Activity in the starch, gelatin and urease tests were strain-variable, and in many instances were at variance with published data (Kocur et al., I972; Kocur \& Martinec, 1972). The deviations in biochemical characters observed here might be explained by the fact that cultural conditions influenced strain instability in the expression of some phenotypes although genotypic loci exist for these characters. Although the laboratory isolates differed from each other in these variable properties, they corresponded biochemically with some of the designated $M$. luteus strains. Thus, it is possible that YPO2, YP07, YPIO and YPI5 may be identical isolates of already existing strains. Attempts to isolate strains biochemically typical of $M$. varians were unsuccessful.

Electrophoretic separations of cellular proteins from the extracts of $M$. luteus strains (including those from the four isolates) stained for catalase activity, consistently exhibited two isoenzyme bands (Fig. I $a, b$ ). With a few minor exceptions, these patterns appeared uniformly similar. In each, the major band was achromatic and broad and of similar electrophoretic mobility, except in AUCC8I in which the major band was slightly more mobile. After staining, the single minor isoenzyme band was visualized either as an achromatic band, generally sharply delineated, or as a chromogenic band as in the patterns from AUCC SL233 and ATCCI I880. Gregory \& Fridovich (1974) described the appearance of such chromogenic bands as enzyme activity associated with peroxidase or with low levels of catalase. To distinguish between these possibilities, control staining assays were made by preparing gels from the extracts of AUCC SL233 and ATCCII 880 and soaking them in the peroxidase-deficient mixture followed by soaking in the $\mathrm{H}_{2} \mathrm{O}_{2}$ substrate. On these reacted gels neither the major achromatic band nor the minor chromogenic band developed, thus establishing the catalase nature of the latter components. The quality of the minor band from AUCC SL233 and ATCCII 880 is probably not different from those of the minor achromatic bands in the patterns from the other $M$. luteus strains, since all these bands had nearly equivalent electrophoretic mobility. This suggests that in AUCC SL233 and ATCCI I 880 the minor isoenzyme component constituted a quantitatively low but detectable contribution to the total catalase activity (not determined) contained in their respective extracts.

Fig. I. Catalase isoenzyme patterns from (a) M. luteus strains and (b) laboratory isolated strains. (a) (A) M. luteus ATCC4698; (B) M. lysodeikticus AUCC PII9; (C) M. lysodeikticus AUCC XL30; (D) $M$. flavus ATCCI0240; (E) M. flavus AUCC8I; (F) $M$. sodonensis ATCCII880; (G) M. luteus AUCCI226; (H) Sarcina subflava ATCC7468; (I) S. flava AUCC22; (J) S. lutea ATCC38I ; (K) S. lutea AUCC SL233. (b) (A) YPO2; (B) YPO7; (B) YPIO; (D) YPI5. Migration is from top to bottom.

Fig. 2. Catalase isoenzyme patterns from $M$. varians strains. (A) Staphylococcus lactis ATCCI5306; (B) $M$. varians ATCC399 (vertical arrows show position of minor bands); (C) S. aurantiaca ATCCI46 (horizontal arrow indicates peroxidase band); (D) M. pulcher ArcCI 5936. Migration is from top to bottom. 
In contrast, the enzyme activity patterns produced by extracts of $M$. varians (ATCCI 5306, ATCC399, ATCCI 46 and ATCCI5936) exhibited three catalase isoenzymes; one major and two minor bands (Fig. 2). In ATCCI46 the dense staining band (shown by arrow) proved to be a peroxidase active band. It can be seen that two types of intraspecies pattern developed, which differed in the location of the major band. The patterns from ATCCI5306 and ATCC 399 were identical, the major band in each being the rapidly-migrating isoenzyme. For ATCCI 46 and ATCCI5936 the major catalase band migrated more slowly and was located unequally between the minor isoenzymes. Whether these differences are limited to the strains examined here or are indeed typical of catalases from other unexamined strains of $M$. varians cannot be evaluated from these few results. Studies have been undertaken to examine this question.

Strain ATCCI 46 differed from the other $M$. varians strains tested in possessing peroxidase activity, and differed biochemically by its inability to reduce nitrate (Table I). Although ATCCI 46 was not included in the redefinition of the taxonomic status of $M$. luteus (Kocur et al., I972) or $M$. varians (Kocur \& Martinec, I972), it seems appropriate from my results to include this strain with $M$. varians. The reported GC content in DNA of ATCCI $46(68 \%)$ is in keeping with this classification (Kocur et al., 197I; Rosypalová et al., 1966). The inability of ATCCI 46 to reduce nitrate was not considered to be an excluding property since Kocur \& Martinec (1972) reported nitrate reduction in $80 \%$ of the $M$. varians strains tested.

The differentiation of $M$. luteus and $M$. varians by their catalase isoenzyme patterns agreed with their differentiation by biochemical tests. Micrococcus luteus strains, which do not reduce nitrate or produce acid from glucose, are further characterized by a catalase pattern consisting of one minor and one major band. In comparison, $M$. varians strains, which are generally positive for these properties, possess three forms of the enzyme catalase which can be demonstrated electrophoretically. Further, the four laboratory isolates which were identified as strains of $M$. luteus by biochemical tests exhibited catalase isoenzyme patterns consistent with those characteristic of this species. Despite the limitations of the catalase activity assay as a tool in systematic bacteriology, my results show the usefulness of the method in the genus Micrococcus at the intrageneric level. The results also indicate the possibility that the catalase activity assay may be useful in differentiating strains of $M$. varians at the intraspecies level.

I acknowledge with thanks the technical assistance of Mr J. Fuller.

\section{REFERENCES}

BAIRD-PARKer, A. C. (1974). Gram-positive cocci. In Bergey's Manual of Determinative Bacteriology, 8th edn, pp. $47^{--528}$. Edited by R. E. Buchanan and N. E. Gibbons. Baltimore: The Williams \& Wilkins Co.

BoháČEK, J., Kocur, M. \& MARTinec, T. (1967). DNA base composition and taxonomy of some micrococci. Journal of General Microbiology 46, 369-376.

BoháČEK, J., Kocur, M. \& MARTINeC, T. (1970). DNA base composition of some Micrococcaceae. Microbios 6, 85-9I.

Fox, R. H. (1975). Taxonomic characterization of some yellow-pigmented micrococci by polyacrylamide gel electrophoresis of soluble proteins. Microbios I3, I05-I IO.

Fox, R. H. \& MCClain, D. E. (I974). Evaluation of the taxonomic relationship of Micrococcus cryophilus, Branhamella catarrhalis, and Neisseriae by comparative polyacrylamide gel electrophoresis of soluble proteins. International Journal of Systematic Bacteriology 24, 172-176.

Gregory, E. M. \& Fridovich, I. (I974). Visualization of catalase on acrylamide gels. Analytical Biochemistry 58, 57-62. 
Kocur, M., Bergan, T. \& Mortensen, N. (I97I). DNA base composition of Gram-positive cocci. Journal of General Microbiology 69, I67-183.

Kocur, M. \& Martinec, T. (I972). Taxonomic status of Micrococcus varians Migula I 900 and designation of the neotype strain. International Journal of Systematic Bacteriology 22, 228-232.

Kocur, M., Páčová, Z. \& Martinec, T. (1972). Taxonomic status of Micrococcus luteus (Schroeter 1872) Cohn 1872 and designation of the neotype strain. International Journal of Systematic Bacteriology 22, 2 r8-223.

Lowry, O. H., Rosebrough, N. J., Farr, A. L. \& Randall, R. J. (I95I). Protein measurement with the Folin phenol reagent. Journal of Biological Chemistry 193, 265-275.

Rosypal, S., Rosypalová, A. \& HořJě̌, J. (I966). The classification of micrococci and staphylococci based on their DNA base composition and Adansonian analysis. Journal of General Microbiology 44, $28 I-292$.

Rosypalová, A., BoháčeK, J. \& Rosypal, S. (I966). Deoxyribonucleic acid base composition of some micrococci and sarcinae. Antonie van Leeuwenhoek 32, 192-196.

VENNER, H. (1967). Taxonomy of Sarcina on the basis of their DNA base composition. Acta Biochimica Polonica 14, 3I-40. 